\title{
Meningkatkan Perkembangan Membaca melalui Buku Cerita Rakyat Melayu pada Anak Usia Dini
}

\author{
Rita Kurnia ${ }^{\otimes_{1}}$, Guslinda Guslinda ${ }^{2}$, Maria Safriyanti ${ }^{3}$ \\ Pendidikan Guru Pendidikan Anak Usia Dini, Universitas Riau ${ }^{1}$ \\ Pendidikan Guru Sekolah Dasar Dini, Universitas Riau ${ }^{2}$ \\ Pendidikan Bahasa Inggris Universitas Riau ${ }^{3}$ \\ DOI: $\underline{10.31004 / \text { obsesi.v4i2.457 }}$
}

\begin{abstract}
Abstrak
Penelitian ini bertujuan untuk mendeskripsikan proses dan hasil pembelajaran melalui pelaksanaan penggunaan media gambar yang dapat meningkatkan kesiapan membaca anak usia dini di Taman Kanak-Kanak Pembina Negeri Tualang Kabupaten Siak, Riau. Metode penelitian ini adalah Tindakan Kelas (PTK). Subyek penelitian ini berjumlah 19 orang anak usia 5-6 tahun. Penelitian ini terdiri dari dua siklus dan setiap siklus terdiri dari tiga pertemuan.Teknik analisis data digunakan dalam penelitian ini adalah analisis data kuantitatif dan kualitatif. Analisis data kualitatif dengan cara menganalisis data dari hasil catatan observasi, wawancara, dan dokumentasi. Hasil penelitian ini menunjukkan adanya peningkatan kesiapan membaca anak melalui media gambar adalah rata-rata skor kesiapan membaca anak pada siklus I sebesar $47,37 \%$ dan siklus II meningkat sebesar $76,15 \%$. Kesimpulan, penggunaan media gambar dapat meningkatkan kesiapan membaca anak usia dini.
\end{abstract}

Kata kunci: media gambar; kesiapan membaca; anak usia dini

\begin{abstract}
This study aimed to describe the process and learning outcomes through the implementation of the use of image media that can improve readiness in early childhood reading in the Kindergarten Developers in Tualang State, Siak Regency, Riau. This research method was Classroom Action (CAR). The subjects of this study were 19 children aged 5-6 years. This research consisted of two cycles and each cycle consisted of three meetings. Qualitative data analysis by analyzing data from observations, interviews and documentation. Quantitative data analysis with descriptive statistics was to compare the results obtained by the first cycle and the second cycle. The results of this study indicatedthe improvement on readiness of children through reading media. The results showed that the average score of readiness of children in the first cycle of $47.37 \%$ and the second cycle increased by $76.15 \%$. In conclusion, the use of Riau Malay Folklore media can increase readiness in early childhood reading
\end{abstract}

Keywords: image media; reading readiness; early childhood.

Copyright (c) 2020 Rita Kurnia, Guslinda Guslinda, Maria Safriyanti

$\triangle$ Corresponding author :

Email Address : kurniarita46@gmail.com (Pekanbaru, Riau, Indonesia)

Received 2 February 2020, Accepted 11 February 2020, Published 14 February 2020 


\section{PENDAHULUAN}

Pendidikan Anak Usia Dini merupakan salah satu bentuk pendidikan prasekolah. Pendidikan prasekolah adalah pendidikan untuk membantu pertumbuhan dan perkembangan jasmani dan rohani anak diluar lingkungan keluarga sebelum memasuki pendidikan dasar (Suardi et al., 2019). Sesuai dengan undang-undang Pendidikan Nasional No 20 Tahun 2003 Pasal 1 ayat 14 menyebutkan bahwa "Pendidikan anak Usia Dini adalah suatu upaya pembinaan yang ditujukan kepada anak sejak lahir sampai dengan usia enam tahun yang dilakukan melalui pemberian rangsangan pendidikan untuk membantu pertumbuhan dan perkembangan jasmani dan rohani agar anak memiliki kesiapan dalam memasuki pendidikan lebih lanjut" (Yanto, 2018). Anak usia dini mempunyai potensi besar untuk mengoptimalkan termasuk keterampilan dalam membaca.

Kemampuan membaca merupakan hal yang penting dalam perkembangan anak. Anak berada pada tahap pemula, sehingga anak perlu dibimbing untuk memperhatikan dua hal persiapan membaca yaitu keteraturan bentuk dan pola gabungan huruf. Menurut Astuti \& Aziz (2019) terdapat beberapa hal yang harus diperhatikan dalam mengajarkan membaca permulaan pada anak salah satunya adalah instrumen yang digunakan.

Keberhasilan kesiapan membaca pada anak usia dini di perlukan adanya instrumen yang tepat untuk perkembangan bahasa khususnya kosa kata anak (Mangen et al., 2019). Namun kenyataannya masih banyak sekolah yang memiliki ketersediaan media pembelajaran yang relatif terbatas seperti jenis media, jumlah media, dan kualitas media sehingga kelancaran pelaksanaan pembelajaran kurang efektif dilaksanakan (Knauer et al., 2020). Selain itu tingkat sosial ekonomi orang tua juga mempengaruhi kemampuan penguasaan kosa kata anak (Ebert, 2020).

Kesiapan membaca sebagai kesempatan pengajaran untuk membaca ketika anakanak siap belajar bagaimana membaca (Astuti \& Aziz, 2019). Melalui karyawisata, akan menambah pengalaman anak, serta mereka dapat mengenal dan mengetahui keadaan lingkungan di luar rumah atau di luar sekolah(Wildová \& Kropá, 2015). Orang tua memainkan peran yang penting dalam menyiapkan anak-anak mereka ke sekolah dasar,seperti aspek bahasa dan komunikasi yang harus diperhatikan (Suardi et al., 2019). Kemampuan bahasa pada anak usia 5-6 tahun berkaitan dengan media audio seperti gerak dan suara serta diri sendiri dan lingkungan sosial paling dekat berkembang dengan baik, bahkan sangat baik(Taja et al., 2019).Media visual memiliki peran dalam meningkatkan kemampuan literasi anak usia dini, contohnya jumlah kosa kata, alur, kesadaran fonologi serta meningkatkan kesiapan membaca dan menulis anak untuk memasuki ke sekolah dasar kelas satu (Mak \& Fancourt, 2020).

Melalui karyawisata, akan menambah pengalaman bagi murid, serta mereka dapat mengenal dan mengetahui keadaan lingkungan di luar rumah atau di luar sekolah (Joni, 2019). Kesiapan anak usia dini dalam aspek bahasa dan komunikasi juga wajar diberi perhatian karena aspek ini merupakan satu faktor pemikiran dalam keberhasilan anak usia dini ketika di sekolah yang akan datang (Noble et al., 2019). Hasil penelitian (Fitriani \& Joni, 2017) menunjukkan bahwa anak usia dini telah mencapai prestasi yang tinggi dalam ujian kosakata, diskriminasi auditori, diskriminasi visual, dan membaca mekanis.

Media pembelajaran yaitu suatu bentuk peralatan, metode, atau teknik yang digunakan dalam menyalurkan pesan, membantu mempertegas bahan pelajaran, sehingga dapat membangkitkan minat dan motivasi murid atau anak didik dalam mengikuti proses belajar mengajar (Guslinda \& Kurnia, 2018). Terkait bacaan (bahasa verbal/berbicara/bercerita) dengan visual atau gambar, hal ini tentunya juga cerita rakyat yang disajikan dengan gambar. Cerita rakyat yang berkembang dalam masyarakat tradisional khususnya untuk masyarakat dahulu salah satunya adalah cerita yang tokohnya binatang dan orang. Cerita rakyat dengan tokoh binatang ini disebut dengan fabel (Anggraeni et al., 2019). Keberadaan cerita rakyat Melayu yang begitu banyak sudah menjadi milik Nasional, khususnya pengembangan bahasa anak. 
Untuk lebih termuatnya nilai-nilai budaya Melayu Riau, maka diangkat cerita-cerita dari rakyat Melayu Riau, diantaranya: 1) Ikan Tongkol dan Bulu Ayam dari Kepulauan Riau; 2) Ikan Patin dari daerah Kampar; 3) Putri Kaca Mayang dari Kota Pekanbaru; dan 4) Putri Tujuh dari Kota Dumai, dengan menggunakan media mekanika elektronika. Fauziddin (2017) Mengatakan bahwa bercerita dengan penokohan legenda berpotensi untuk dijadikan media dalam pembelajaran khususnya dalam meningkatkan kesiapan membaca anak.

Penelitian tindakan ini bertujuan untuk mengetahui penggunaan media cerita bergambar rakyat Melayu Riau untuk meningkatkan kesiapan membaca anak usia dini dan untuk mengetahui keefektifan penggunaan media cerita bergambar rakyat Melayu Riau dalam proses belajar mengajar anak usia dini. Hamidah (2019) mengatakan bahwa kesiapan membaca sebagai kesempatan pengajaran untuk membaca, ketika anak-anak siap belajar bagaimana membaca.

Hasil penelitian Liang et al., (2019) tingkat sosial ekonomi orang tua mempengaruhi kemampuan penguasaan kosakata murid taman kanak-kanak, maka bimbingan dan pengarahan dari seorang guru sangat diperlukan. Adapun hasil penelitian Ability et al., (2018) Sejumlah bukti menunjukkan bahwa faktor khusus di rumah adalah perkiraan yang lebih baik adalah sikap belajar anak usia dini dibandingkan dengan status sosio-ekonomi.

Adapun menurut pendapat Village et al., (2018) yang lebih menekankan kesiapan membaca pada keadaan motivasi diri dan perilaku yang menunjukkan adanya kesiapan mental, kemauan belajar terhadap lingkungan secara umum dan khususnya teks bacaan atau gambar, seperti: 1) Rasa ingin tahu tentang benda-benda di dalam lingkungan, manusia, proses, dan sebagainya; 2) mampu untuk menerjemahkan atau membaca gambar dengan mengidentifikasi dan menggambarnya; 3) menyeluruh dalam pembelajaran; 4) kemampuan berkomunikasi dengan bahasa percakapan khususnya dalam kalimat; 5) kemampuan untuk membedakan dan persamaan serta perbedaan dalam suara secara cukup baik; 6) adanya kengingan untuk belajar membaca; 7) memiliki kemampuan emosional yang cukup untuk dapat konsentrasi dan terus-menerus dalam suatu tugas; 8) memilliki percaya diri dan stabilitas emosi.

Berdasarkan tujuan penelitian, maka penulis tertarik mengangkat judul "Meningkatkan Perkembangan Membaca melalui Buku Cerita Rakyat Melayu pada Anak Usia Dini"

\section{METODOLOGI}

Penelitian dilaksanakan di TK Pembina Negeri Kecamatan Tualang, Kabupaten Siak, Riau. Subyek penelitian anak usia dini berjumlah 19 orang. Metode penelitian ini adalah penelitian tindakan (action research).Tujuannya untuk memperbaiki mutu praktik dalam pembelajaran.(Sugiyono, 2017)mengatakan bahwa penelitian tindakan merupakan penelitian terapan yang fokus pada penelitian tertentu. Dalam perencanaan yang sesuai dengan prosedur penelitian tindakan, secara umum penelitian tindakan terdiri dari beberapa prosedur yaitu: tahap perencanaan tindakan, tahap pelaksanaan tindakan, tahap pengamatan terhadap tindakan, tahap refleksi terhadap tindakan. 


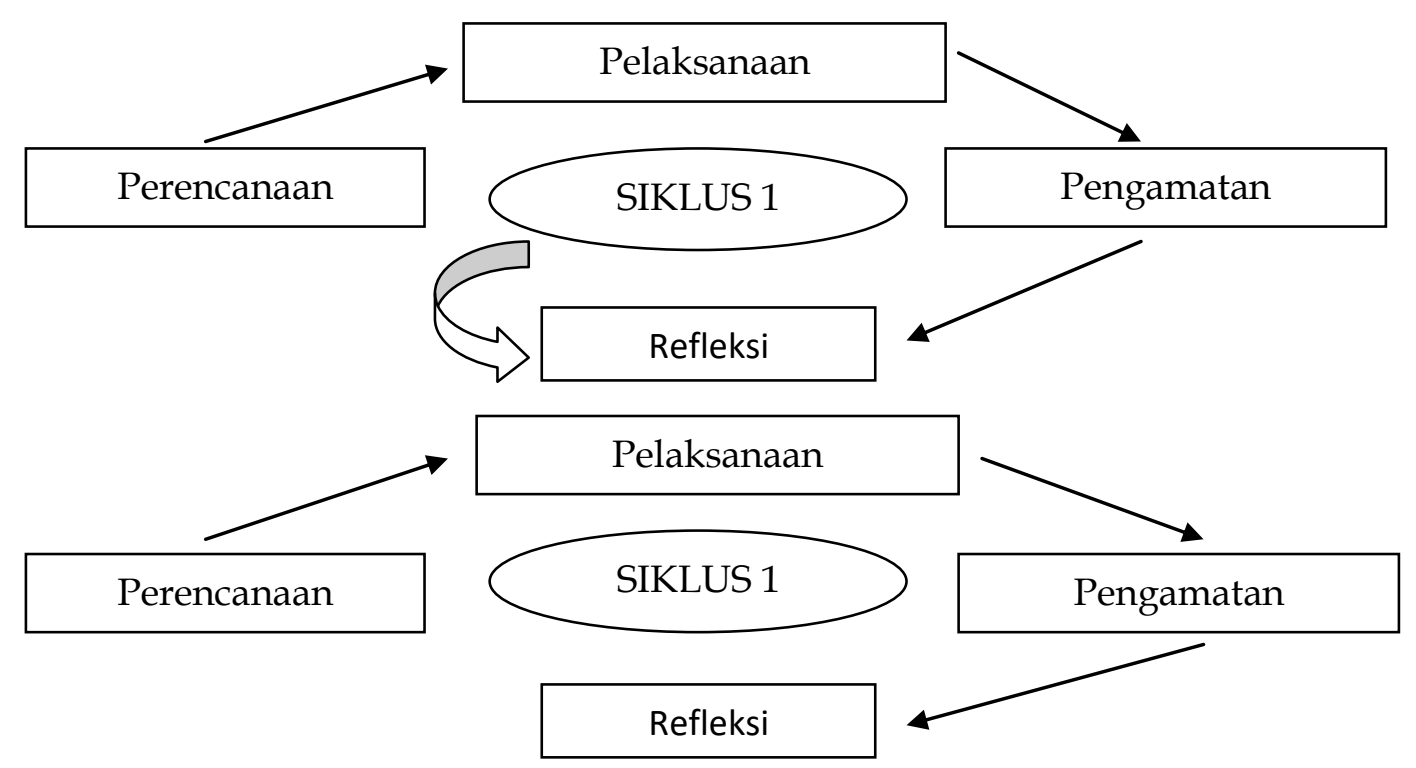

Bagan 1. Alur Penelitian Action Research

Setelah itu, sebagai pedoman dalam membuat instrumen. Konseptual dan definisi operasional tentang kesiapan membaca anak usia 5-6 tahun sebagai berikut:

Tabel 1. Kisi-Kisi Instrumen Kesiapan Membaca

\begin{tabular}{|c|c|c|c|c|c|}
\hline No & Indikator & BB & MB & $\mathrm{BSH}$ & BSB \\
\hline 1 & $\begin{array}{l}\text { Rasa ingin tau tentang benda-benda di lingkungan, } \\
\text { manusia, dan proses kejadian }\end{array}$ & & & & \\
\hline 2 & $\begin{array}{l}\text { Mampu menerjemahkan atau membaca gambar } \\
\text { dengan mengidentifikasi dan menggambarkannya }\end{array}$ & & & & \\
\hline 3 & Meyeluruh dalam pembelajaran & & & & \\
\hline 4 & $\begin{array}{l}\text { Mampu berkomunikasi dengan bahasa percakapan } \\
\text { khususnya dalam kalimat }\end{array}$ & & & & \\
\hline 5 & $\begin{array}{l}\text { Mampu untuk mengungkapkan persamaan dan } \\
\text { perbedaan dalam suara atau bunyi }\end{array}$ & & & & \\
\hline 6 & Keinginan untuk belajar & & & & \\
\hline 7 & $\begin{array}{l}\text { Mampu untuk konsentrasi dalam tugas atau } \\
\text { belajarMemiliki percaya diri dan stabilitas emosi }\end{array}$ & & & & \\
\hline
\end{tabular}

Adapun rumus yang digunakan untuk mengetahui peningkatan kesiapan membaca anak setiap siklus, menggunakan rumus (Arikunto, 2010)sebagai berikut:

$$
P=\frac{\text { Posrate }- \text { Baserate }}{\text { Baserate }} \times 100 \%
$$

Keterangan:

$P$

Posrate : Nilai sudah diberi tindakan

Baserate : Nilai sebelum diberi tindakan

$100 \quad$ : Bilangan tetap 


\section{HASIL DAN PEMBAHASAN}

Pelaksanaan penelitian ini dilakukan di TK Negeri Pembina Tualang di Kecamatan Tualang Kabupaten Siak. Kelompok yang diteliti adalah usia 5-6 tahun atau TK B, jumlah anak didik adalah 19 orang. Pelaksanaan penelitian dilakukan dengan empat tahap yaitu: (1) Tahap perencanaan adalah menyusun rancangan untuk pembelajaran persiapan membaca anak dengan penggunaan media cerita bergambar rakyat melayu Riau semi teknologi. Perencanaan diawali dengan menetapkan kelompok belajar anak dilanjutkan dengan penetapan tema dan sub tema yang dituangkan dalam RPPH untuk empat kali pertemuan; (2) Tahap pelaksanaan, adalah melaksanakan pembelajaran dengan mengacukepada rancangan yang sudah dibuat yaitu pelaksanaan dari RPPH; (3) Tahap mengamati, adalah dilakukan dengan mengisi lembar observasi yaitu lembar observasi aktivitas guru dan aktivitas anak selama mengikuti pembelajaran penggunaan media pelangi semi teknologi; (4) Tahap refleksi, adalah mempertimbangkan kelebihan dan kelemahan guru dalam penyampaian pembelajaran dengan menggunakan media pelangi semi teknologi.

\section{Deskripsi Data Pra-Tindakan}

Langkah awal yang dilakukan oleh peneliti sebelum melakukan penelitian tindakan yaitu melalui pengamatan terhadap keterampilan membaca awal anak. Hal ini dilakukan agar peneliti mengetahui kondisi awal keterampilan membaca anak. Hasil yang akan diperoleh dari pengamatan ini dibandingkan dengan hasil nilai setelah melakukan tindakan. Dengan dilakukan perbandingan antara nilai yang sebelum dengan nilai setelah dilakukan tindakan maka akan dapat diketahui peningkatan yang terjadi dalam proses pembelajaran untuk meningkatkan keterampilan membaca permulaan pada anak. Berdasarkan hasil pengamatan yang dilakukan peneliti, terkait dengan aspek keterampilan membaca selama observasi pembelajaran berlangsung anak mengalami kesulitan dalam mengikuti kegiatan yang melibatkan keterampilan membaca. Pada umumnya anak masih belum memahami isi cerita bergambar yang dilihatkan guru. Anak masih sangat membutuhkan bimbingan dan stimulus agar anak dapat mengembangkan keterampilan membaca tahap permulaan yang berhubungan dengan mengenal kosa kata dan memahami isi cerita.

\section{Tindakan Siklus I}

Tindakan dan pengamatan pada siklus I dilakukan empat kali dalam seminggu sampai mencapai dua belas kali pertemuan. Alokasi waktu dalam pelaksanaan penggunaan media bergambar adalah 60 menit setiap kali pertemuan.

Tahap-tahap pada penelitian ini yaitu perencanaan, pelaksanaan, analisis dan refleksi. Tahap perencanaan tindakan pada siklus I pertemuan pertama mencakup: (1) rencana Program Pembelajaran Harian (RPPH); (2) mempersiapkan media pembelajaran yang digunakan untuk mendukung proses pembelajaran dengan media buku cerita rakyat melayu. (3) menyusun lembar observasi tentang kegiatan keterampilan membaca. Pertemuan pertama dilaksanakan pada hari Rabu, 18 September 2019 dari pukul 7.30- 10.30 WIB dengan tema keluargaku dengan sub tema profesi anggota keluarga. Pembelajaran dimulai dengan penyambutan anak, jurnal pagi, literasi, dan dilanjutkan dengan berbaris Sebelum masuk pada kegiatan inti anak-anak istirahat dulu untuk makan, minum dan bermain. Tema hari ini yaitu mengenai Keluargaku dengan pembahasan profesi anggota keluarga. Langkah dalam proses membaca pada anak dimulai dengan guru mengenalkan media buku cerita kepada anak. Kemudian guru bercerita dengan menggunakan media buku cerita rakyat melayu, selanjutnya anak mendengar dengan seksama, kemudian guru melakukan Tanya jawab mengenai cerita rakyat melayu. 
Pertemuan 2 pada siklus 1 dilaksanakan pada hari jumat 20 September 2019 dari pukul 07.30-10.30 WIB. Dengan tema keluargaku dengan sub tema profesi macam-macam pekerjaan. Kegiatan inti dimulai dengan guru menjelaskan kegiatan yang akan dilakukan hari ini. Guru mengenalkan media buku cerita kepada anak. Kemudian guru bercerita dengan menggunakan media buku cerita rakyat melayu, selanjutnya anak mendengar dengan seksama, kemudian guru melakukan Tanya jawab mengenai cerita rakyat melayu. Setelah itu kegiatan dilanjutkan dengan tanya jawab kegiatan yang dilakukan hari ini, bernyanyi dan doa pulang.

Pertemuan 3 pada siklus 1 dilakukan pada hari sabtu, 21 September 2019 dari pukul 07.30-10.30 WIB. Dengan tema Keluargaku, sub tema macam-macam pekerjaan. Guru menjelaskan kegiatan bercerita pada hari ini. Namun guru memvariasikan dengan menunjukkan anak dengan cara menebak huruf pada media gambar. Pengamatan dilakukan bersamaan dengan pendampingan dalam pembelajaran. Pada psoses pembelajaran siklus 1 selama 3 pertemuan dari kegiatan awal sampai dengan akhir berjalan dengan baik dan lancar sesuai dengan yang telah direncanakan. Berikut hasil peningkatan saat tindakan dan siklus I:

\section{Tabel 2. Kesiapan Membaca Siklus I}

\begin{tabular}{|c|c|c|c|c|c|c|}
\hline \multirow{2}{*}{ No } & \multirow[b]{2}{*}{ Kode Subyek } & \multicolumn{2}{|c|}{ Siklus 1} & \multirow{2}{*}{ Jumlah } & \multirow[b]{2}{*}{ Skor Ideal } & \multirow{2}{*}{ Kriteria } \\
\hline & & Pert I & Pert II & & & \\
\hline 1 & $\mathrm{AH}$ & 41 & 47 & 88 & 44 & MB \\
\hline 2 & AKA & 47 & 50 & 97 & 48,5 & MB \\
\hline 3 & ALK & 41 & 50 & 91 & 45,5 & MB \\
\hline 4 & ARP & 44 & 56 & 100 & 50 & MB \\
\hline 5 & $\mathrm{AA}$ & 41 & 56 & 97 & 48,5 & MB \\
\hline 6 & ASH & 44 & 50 & 94 & 47 & MB \\
\hline 7 & CS & 41 & 56 & 97 & 48,5 & MB \\
\hline 8 & DNQ & 41 & 59 & 100 & 50 & MB \\
\hline 9 & DAS & 53 & 56 & 109 & 54,5 & $\mathrm{BSH}$ \\
\hline 10 & FAB & 41 & 47 & 88 & 44 & MB \\
\hline 11 & FAI & 41 & 56 & 97 & 48,5 & MB \\
\hline 12 & MR & 50 & 59 & 109 & 54.5 & $\mathrm{BSH}$ \\
\hline 13 & MK & 50 & 56 & 106 & 53 & $\mathrm{BSH}$ \\
\hline 14 & MFM & 41 & 59 & 100 & 50 & MB \\
\hline 15 & NUR & 53 & 62 & 115 & 57,5 & $\mathrm{BSH}$ \\
\hline 16 & RA & 44 & 59 & 103 & 51,5 & BSH \\
\hline 17 & $\mathrm{ZA}$ & 53 & 56 & 109 & 54,5 & $\mathrm{BSH}$ \\
\hline 18 & ZMR & 44 & 62 & 106 & 53 & $\mathrm{BSH}$ \\
\hline 19 & $\mathrm{RM}$ & 44 & 59 & 103 & 51,5 & $\mathrm{BSH}$ \\
\hline & Jumlah & 854 & 1055 & 1909 & 900 & \\
\hline & Skor Ideal & 44,94 & 55,53 & 100,47 & 47,37 & MB \\
\hline
\end{tabular}

Dari tabel di atas dapat dilihat bahwa kesiapan membaca anak mulai ada peningkatan setelah diberi tindakan berupa penggunaan media gambar. Pada siklus I,19 anak diberi tindakan, terdapat delapan anak yang tertinggi dan masuk kategori berkembang sesuai harapan (BSH) yaitu skor ideal sebesar 54 dan sebesar 57.Sebelas anak lainnya mengalami peningkatan dan masuk dalam kategori mulai berkembang (MB). Rata-rata anak pada pertemuan pertama sebesar 44,94 mengalami peningkatan menjadi 55,53 pada siklus I. Berdasarkan kategori yang ditentukan sebelumnya, rata-rata pada siklus I termasuk dalam kategori mulai berkembang (MB). Setelah melakukan tindakan dalam enam kali pertemuan, peneliti dan kolaborator melakukan refleksi untuk perbaikan pada siklus II. 
Hasil refleksi yang telah didiskusikan oleh peneliti bersama kolaborator adalah: (1) guru masih kurang dalam merangsang anak untuk menggunakan media atau alat peraga disaat mengajar; (2) anak tidak berminat dengan media gambar; (3) beberapa anak malu tampil ke depan kelas; (4) guru membuat satu permainan tebak-tebak huruf untuk menampilkan media gambar; (5) guru menunjukkan anak dengan cara menebak huruf pada media gambar; dan (6) pada siklus I hanya empat anak yang sudah tahap mulai berkembang sesuai harapan, hal ini berarti bahwa penelitian belum sesuai harapan, sehingga penelitian akan dilanjutkan pada siklus II.

\section{Tindakan Siklus II}

Berdasarkan hasil observasi dan refleksi siklus 1, peneliti menyusun rencana pelaksanaan penelitian siklus 2, Perencanaan tersebut meliputi: (1) melakukan koordinasi dengan rekan mengajar sebagai kolaborator peneliti; (2) menyususn RPPH; (3) Mempersiapkan media dan alat; dan (4) mempersiapkan kamera untuk dokumentasi.

Tindakan pada siklus II adalah peningkatan kesiapan membaca anak melalui penggunaan media gambar dengan beberapa perbaikan berdasarkan refleksi siklus I. Tahaptahap pada penelitian tindakan adalah tahap perencanaan, tindakan dan pengamatan, dan refleksi. Perencanaan tindakan sama dengan siklus I, tetapi dilakukan perbaikan pada proses tindakan siklus II adalah mengkondisikan anak untuk melakukan kompetisi, memberi stimulasi lebih pada anak yang masih kurang kesiapan membacanya, menstimulasi anak untuk berani berbicara dengan lancar, memberi stimulasi agar anak ada kemampuan bercerita kembali setelah melihat media gambar berupa cerita rakyat melayu. Pada perencanaan siklus II, dilakukan perbaikan pembelajaran sesuai hasil refleksi pada siklus I. Perbaikannya adalah memberikan media cerita yang menarik seperti buku cerita ada warna warni yang disenangi anak pada siklus II. Proses kegiatan pembelajaran selama enam kali pertemuan.

Pertemuan pertama pada siklus 2 dilaksanakan pada hari senin, 7 Oktober 2019 dari pukul 7.30-10.30 WIB.Tema yang digunakan adalah Keluargaku, dengan sub tema macammacam pekerjaan. Sebelum masuk kegiatan inti guru melakukan Tanya jawab tentang bercerita yang dilakukan sebelumnya. Guru bercerita dengan menggunakan media buku cerita rakyat melayu yang dimulai dari mengenalkan judul cerita dan dilanjutkan dengan guru bercerita. Selanjutnya anak diminta kembali menceritakan apa yang diceritakan guru. Kegiatan selanjutnya anak menghubungkan gambar dengan beberapa kata. Setelah itu kegiatan dilanjutkan dengan Tanya jawab kegiatan yang dilakukan hari ini, bernyanyi dan doa pulang, selesai berdoa guru mengucap salam dan anak menjawab salam, anak keluar kelas sambil berpamitan dan mencium tangan guru.

Pertemuan 2 siklus 2 dilaksanakan pada hari rabu 9 Oktober 2019 dari pukul 7.3010.30 WIB. Dengan tema Lingkunganku, sub tema lingkungan sekolahku. Langkah dalam pembelajaran menggunakan media buku cerita rakyat melayu masih sama dengan teknik pada pertemuan sebelumnya. Namun yang berbeda adalah pada pertemuan kedua ini dilakukan diruangan terbuka atau dilingkungan diluar sekolah dengan teknik karyawisata.

Pertemuan 3 siklus 2 dilaksanakan pada hari jumat, 11 november 2019 dari pukul 7.30-10.30 WIB. Dengan tema Lingkunganku, sub tema lingkungan sekolahku. Guru mengajak anak bercerita diluar ruangan agar anak tidak merasa bosan dan jenuh. Pengamatan dilakukan bersamaan dengan pendampingan dalam pembelajaran. Pada proses pembelajaran siklus 2 selama 3 pertemuan dari kegiatan awal sampai dengan kegiatan akhir berjalan dengan baik sesuai yang telah direncanakan. Berikut hasil peningkatan siklus II: 
Tabel 3. Kesiapan Membaca Siklus II

\begin{tabular}{|c|c|c|c|c|c|c|}
\hline \multirow{2}{*}{ No } & \multirow{2}{*}{$\begin{array}{c}\text { Kode } \\
\text { Subyek }\end{array}$} & \multicolumn{2}{|c|}{ Siklus II } & \multirow{2}{*}{ Jumlah } & \multirow[t]{2}{*}{ Skor Ideal } & \multirow{2}{*}{ Kriteria } \\
\hline & & Pert I & Pert II & & & \\
\hline 1 & $\mathrm{AH}$ & 65,62 & 75 & 140,62 & 70,31 & BSH \\
\hline 2 & AKA & 71,87 & 84,4 & 156,27 & 78,13 & BSB \\
\hline 3 & ALK & 75 & 84,4 & 159,4 & 79,7 & BSB \\
\hline 4 & ARP & 68,75 & 84,4 & 153,15 & 76,6 & BSB \\
\hline 5 & AA & 71,87 & 68,7 & 140,57 & 70,3 & $\mathrm{BSH}$ \\
\hline 6 & ASH & 71,87 & 84,4 & 156,27 & 78,13 & BSB \\
\hline 7 & CS & 75 & 84,4 & 159,4 & 79,7 & BSB \\
\hline 8 & DNQ & 68,75 & 81,2 & 149,95 & 74,97 & $\mathrm{BSH}$ \\
\hline 9 & DAS & 65,62 & 84,4 & 150,02 & 75,01 & $\mathrm{BSH}$ \\
\hline 10 & FAB & 75 & 87,5 & 162,5 & 81,25 & BSB \\
\hline 11 & FAI & 78,12 & 84,4 & 162,52 & 81,26 & BSB \\
\hline 12 & MR & 68,75 & 75 & 143,75 & 71,9 & $\mathrm{BSH}$ \\
\hline 13 & MK & 71,87 & 78,2 & 150,07 & 75,03 & $\mathrm{BSH}$ \\
\hline 14 & MFM & 65,62 & 84,4 & 150,02 & 75,01 & $\mathrm{BSH}$ \\
\hline 15 & NUR & 78,12 & 75 & 153,12 & 76,56 & BSB \\
\hline 16 & RA & 65,62 & 71,9 & 137,52 & 68,62 & BSH \\
\hline 17 & ZA & 78,12 & 78,1 & 156,22 & 78,11 & BSB \\
\hline 18 & ZMR & 68,75 & 87,5 & 156,25 & 78,12 & BSB \\
\hline 19 & RM & 75 & 81,2 & 156,2 & 78,1 & BSB \\
\hline \multicolumn{2}{|c|}{ Jumlah } & 1359,32 & 1534,5 & 2893,82 & 1446,81 & \\
\hline \multicolumn{2}{|c|}{ Skor Ideal } & 71,54 & 80,76 & 152,3 & 76,15 & BSB \\
\hline
\end{tabular}

Berdasarkan data di atas, terdapat pada pertemuan satu, sudah berkembang sesuai harapan (BSH) sebanyak delapan anak dengan skor idealnya sebesar 68,62 sampai dengan 75,03 . Walaupun demikian, kesiapan membaca anak berkembang sesuai harapan setelah diberi pemberitahuan atau penjelasan pada siklus I dan siklus II.Pada pertemuan kedua sudah ada peningkatan berkembang sangat baik (BSB) sebanyak 14 anak dengan skor ideal sebesar 81,2 sampai dengan 87,5. Rata-rata anak pada siklus II termasuk dalam kategori berkembang sangat baik (BSB). Pada awal penelitian, sudah ditentukan adalah $76,15 \%$ dari jumlah anak yaitu 14 dari 19 anak berkembang sangat baik. Terdapat peningkatan dari siklus I ke siklus II sebesar 51\%. Dengan adanya peningkatan yang cukup tinggi yang terjadi pada siklus II ini, menandakan bahwa kesiapan anak untuk membaca sudah baik.

Dari hasil penelitian dapat disimpulkan bahwa kesiapan membaca anak kelompok B TK Negeri Pembina Tualang Kabupaten Siak Riau dapat meningkat melalui penggunaan media gambar.Setelah melakukan tindakan dalam enam kali pertemuan, peneliti, dan kolaborator melakukan refleksi setelah melaksanakan siklus II. Hasil refleksi yang telah didiskusikan oleh peneliti bersama kolaborator adalah: (1) guru sudah maksimal dalam merangsang anak untuk menggunakan media atau alat peraga disaat mengajar; (2) anak berminat dengan media gambar dan sangat senang; (3) sebagian besar anak tampil ke depan kelas menggunakan media gambar; (4) anak bersemangat dan aktif menggunakan media gambar sambil bercerita di depan kelas; (5) selama pelaksanaan siklus II anak sudah menunjukkan peningkatan kesiapan membaca dengan rata-rata $76,15 \%$. Hal ini membuktikan bahwa penggunaan media gambar dapat meningkatkan kesiapan membaca anak kelompok B TK Negeri Pembina Tualang Kabupaten Siak Riau. Di bawah ini adalah grafik kesiapan membaca anak. 


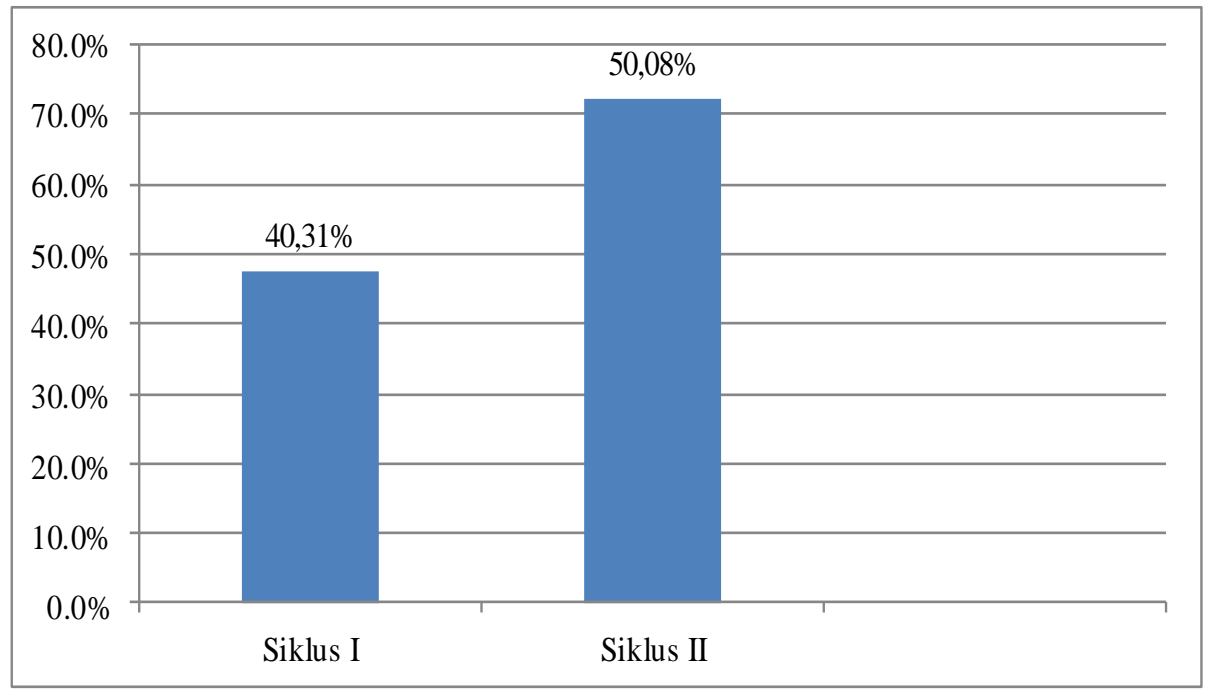

Gambar 1.Kesiapan Membaca Siklus I dan Siklus II

Pada gambar di atas, menunjukkan ada peningkatan siklus I diperoleh hasil rata-rata persentase sebesar $47,71 \%$, kemudian meningkat menjadi $72,17 \%$, setelah diberikan tindakan pada siklus II. Dari hasil pengamatan yang dilakukan, terjadi peningkatan sebesar $51 \%$ dari siklus I ke siklus II sehingga peneliti tidak melanjutkan ke siklus selanjutnya. Dengan adanya peningkatan yang terjadi pada siklus II, ini menunjukkan bahwa anak didik kelompok B1 TK Negeri Pembina Tualang Kabupaten Siak Riau, sudah memiliki kesiapan untuk membaca.

\section{SIMPULAN}

Penggunaan media cerita bergambar dapat meningkatkan kesiapan membaca anak usia dini di Taman Kanak-Kanak Pembina Negeri Siak, Riau. Terbukti dari rata-rata pada tindakan siklus I adalah sebesar 47,37\% dan siklus II meningkat lagi adalah sebesar 76,15\%. Untuk kedepannya guru Taman Kanak-kanak atau pendidik anak usia dini diharapkan mengembangkan kesiapan membaca anak,menggunakan media pembelajaran berbasis teknologi bagi anak usia dini. Khususnya guru pendidikan anak usia dini di Riau, bahwa ada potensi mengembangkan dan mengenalkan cerita rakyat Melayu Riau berbasis budaya lokal bagi anak usia dini.

\section{UCAPAN TERIMAKASIH}

Peneliti mengucapkan terima kasih kepada pihak sekolah yang telah senantiasa mengijinkan dan memberikan kesempatan kepada peneliti untuk melakukan penelitiandan terimakasih juga kepada Jurnal Obsesi : Jurnal Pendidikan Anak Usia Dini yang telah memberikan masukan dalam penulisan artikel ini.

\section{DAFTAR PUSTAKA}

Ability, I., Calis, W., Dwiyanti, L., Khan, R. I., \& Kurniawati, E. (2018). Jurnal Obsesi : Jurnal Pendidikan Anak Usia Dini Development of Smart Adventure Games to Improve the Readiness of the. 2(2), 149-154. https://doi.org/10.31004/obsesi.v2i2.91

Anggraeni, D., Hartati, S., \& Nurani, Y. (2019). Jurnal Obsesi : Jurnal Pendidikan Anak Usia Dini Implementasi Metode Bercerita dan Harga Diri dalam Meningkatkan Kemampuan Berbicara Anak Usia Dini. 3(2), 404-415. https:/ / doi.org/10.31004/obsesi.v3i2.224

Arikunto, S. (2010). Penilitian Tindakan Kelas. Alfabeta.

Astuti, R., \& Aziz, T. (2019). Jurnal Obsesi: Jurnal Pendidikan Anak Usia Dini Integrasi 
Pengembangan Kreativitas Anak Usia Dini di TK Kanisius Sorowajan Yogyakarta. 3(2), $294-$ 302. https://doi.org/10.31004/obsesi.v3i2.99

Ebert, S. (2020). Journal of Experimental Child Theory of mind, language, and reading: Developmental relations from early childhood to early adolescence. Journal of Experimental Child Psychology, 191, 104739. https://doi.org/10.1016/j.jecp.2019.104739

Fauziddin, M. (2017). Jurnal Obsesi: Jurnal Pendidikan Anak Usia Dini Upaya Peningkatan Kemampuan Bahasa Anak Usia 4-5 Tahun melalui Kegiatan Menceritakan Kembali Isi Cerita di Kelompok Bermain Aisyiyah Gobah Kecamatan Tambang. 1(1), 42-51. https:// doi.org/10.31004/obsesi.v1i1.30

Fitriani, N., \& Joni. (2017). Peningkatan Kemampuan Berbicara Anak Melalui Media Cerita Bergambar Anak Kelompok B TK Ayu Smart Kids Batubelah. PAUD Lectura: Jurnal Pendidikan Anak Usia Dini, 1(1).

Guslinda, \& Kurnia, R. (2018). Media Pembelajaran Anak Usia Dini. Jakad Publishing. https:// doi.org/10.13057/ijap.v4i02.4978

Hamidah, J. (2019). Pola Asuh Orsng tua terhadap Kesantunan Berbahasa Anak Usia Dini (Kajian Pragmatik). 1(1), 9-16.

Joni. (2019). Penerapan Metode Bernyanyi untuk Meningkatkan Perkembangan Kosa Kata Anak Usia Dini. Journal on Early Childhood Education Research, 6034(1), 9-16.

Knauer, H. A., Jakiela, P., Ozier, O., Aboud, F., \& Fernald, L. C. H. (2020). Early Childhood Research Quarterly Enhancing young children' s language acquisition through parent - child book-sharing: A randomized trial in rural Kenya. Early Childhood Research Quarterly, 50, 179-190. https:// doi.org/10.1016/j.ecresq.2019.01.002

Liang, H., Vuong, A. M., Xie, C., Webster, G. M., Sjödin, A., Yuan, W., Miao, M., Braun, J. M., Dietrich, K. N., Yolton, K., Lanphear, B. P., \& Chen, A. (2019). Childhood polybrominated diphenyl ether ( PBDE ) serum concentration and reading ability at ages 5 and 8 years: The HOME Study Environment International, 122(February 2018), 330-339. https:/ / doi.org/10.1016/j.envint.2018.11.026

Mak, H. W., \& Fancourt, D. (2020). Reading for pleasure in childhood and adolescent healthy behaviours: Longitudinal associations using the Millennium Cohort Study. Preventive Medicine, 130(June 2019), 105889. https:/ / doi.org/10.1016/j.ypmed.2019.105889

Mangen, A., Hoel, T., Jernes, M., \& Moser, T. (2019). Shared, dialogue-based reading with books vs tablets in early childhood education and care : Protocol for a mixed-methods intervention study. International Journal of Educational Research, 97(June), 88-98. https:// doi.org/10.1016/j.ijer.2019.07.002

Noble, C., Sala, G., Peter, M., Lingwood, J., Rowland, C., Gobet, F., \& Pine, J. (2019). The impact of shared book reading on children' s language skills: A. Educational Research Review, 28(October 2018), 100290. https:/ / doi.org/10.1016/j.edurev.2019.100290

Suardi, I. P., Syahrul, R., \& Asri, Y. (2019). Jurnal Obsesi : Jurnal Pendidikan Anak Usia Dini Pemerolehan Bahasa Pertama pada Anak Usia Dini. 3(1), 265-273. https:// doi.org/10.31004/obsesi.v3i1.160

Sugiyono. (2017). Metode Penelitian dan Pengembangan. Alfabeta. https://doi.org/10.31004/obsesi.v3i2.260

Taja, N., Inten, D. N., \& Hakim, A. (2019). Jurnal Obsesi : Jurnal Pendidikan Anak Usia Dini Upaya Meningkatkan Keterampilan Mengajar Baca Tulis Al-Qur 'An bagi Guru. 3(1), 6881. https://doi.org/10.31004/obsesi.v3i1.135

Village, W., Regency, L., Nur, Y., \& Sary, E. (2018). Jurnal Obsesi : Jurnal Pendidikan Anak Usia Dini Relationship of Parenting with Child Interpersonal Intelligence in. 2(2), 137-142. https:/ / doi.org/10.31004/obsesi.v2i2.93

Wildová, R., \& Kropá, J. (2015). Early Childhood Pre-reading Literacy Development. 191, 878-883. https:// doi.org/10.1016/j.sbspro.2015.04.418 